\title{
Formulation and Examination of Organic Oil and Shampoo from Fish Scales
}

\author{
Ramya Petchimuthu, Angelin Jenit Franklin, Maria Agnes Roganzia Sahayaraj, Abisha \\ Gopalan, Mari Selva Sundari Raju, Vanavil B.
}

\begin{abstract}
Cosmetics are utilized to upgrade the appearance or scent of the human body. Beautifying agents incorporate skin creams, lotions, powders, aromas, lipsticks, fingernail and toe nail polish, eye and facial cosmetics, permanent waves, and numerous different kinds of items. To make the hair sound and gleaming, there are several manufactured oils and hair shampoos. But when in contrast to the artificial one, natural cosmetics have growing demand in the world market and are an priceless gift of nature, as it is secure and free from facet results like hair fall and damage. As it is safe and free from symptoms like hair fall and harm. As the age increases, people suffer from hair loss and damage due to the less secretion of keratin. As we age, our body's natural levels of collagen decrease, leading to thinning and shedding of hair. Research shows that collagen may support and increase hair-building proteins (keratin) in the body. This can help strengthen hair strands, promote hair growth and prevent hair loss. Collagen may even help to prevent the appearance of grey hairs by supporting the healthy structure of the hair follicle, where the pigment of hair is produced. Collagen supplements also have been shown to be effective in treating dry, brittle hair, helping to maintain healthy moisture levels in the hair. The present work was aimed to formulate organic oil and shampoo using fish scales and various herbs. The formulated organic oil and shampoo were evaluated for homogeneity, appearance, odour, saponification value, $\mathrm{pH}$ etc.
\end{abstract}

Keywords: Cosmetics, Keratin, Collagen, saponification value

\section{INTRODUCTION}

Beauty care products are used to upgrade the appearance or odor of the human body [1]. The significant foundation to showcase this readiness is that it ought to be protected and free from any hazardous reactions. Hairs are the indispensable piece of human excellence. Individuals are utilizing herbs for cleaning, decorating and overseeing hair since the ancient time. As the time passed, synthetic agents have taken a large share but at the same time, individuals

Revised Manuscript Received on December 15, 2019.

* Correspondence Author

Ramya Petchimuthu*, Department of Biotechnology, Kalasalingam Academy of Research and Education, Krishnankoil, Tamilnadu, India, p.ramya@klu.ac.in .

Angelin Jenit Franklin, Department of Biotechnology, Kalasalingam Academy of Research and Education, Krishnankoil, Tamilnadu, India, fjajfrank@gmail.com.

Maria Agnes Roganzia Sahayaraj, Department of Biotechnology, Kalasalingam Academy of Research and Education, Krishnankoil, Tamilnadu, India, agnesroganzia@gmail.com

Abisha Gopalan, Department of Biotechnology, Kalasalingam Academy of Research and Education, Krishnankoil, Tamilnadu, India, sahayaabi0302@gmail.com.

Mari Selva Sundari Raju, Department of Biotechnology, Kalasalingam Academy of Research and Education, Krishnankoil, Tamilnadu, India, raviraj68711@gmail.com.

Vanavil B, Department of Biotechnology, Kalasalingam Academy of Research and Education, Krishnankoil, Tamilnadu, India, b.vanavil@klu.ac.in. are getting mindful of destructive consequences for hairs, skin and eyes. These reasons pulled the community towards the use of natural items, which are more affordable and have immaterial reactions [2]. Also, when contrasted with the manufactured commercial one, organic beauty care products have developed increasing interest in the world market as it is free from reactions like hair fall and damage. To make the hair solid and gleaming, there are numerous manufactured oils and hair shampoos [3]. As the age expands, individuals experience the ill effects of male pattern baldness and harm because of the less secretion of keratin. Hair oil and shampoo are utilized for purging reason as well as for conferring gleam to hair and keep up their sensibility and sleekness for hair [4]. In this perspective, the present study focused on the formulation and development of harmless organic hair oil and shampoo from waste fish scales. The ingredients used for the preparation and its respective functions are highlighted below.

\section{Fish scales:}

Fish scales are utilized as a source of collagen. Bovine, chicken and porcine collagens are utilized in numerous cosmetic items and supplements since it is less expensive to extricate. Marine collagen from skin and scales of fishes are prevalent type of collagen and is 1.5 times more bio-available than bovine or porcine. Collagen can be used for reinforcement and protect from battle harm brought about by free radicals. Hair basically comprised of the protein keratin which utilizes few amino acids to fabricate keratin. Some of which can be found in collagen and therefore expands the keratin secretion when applied on hair [5].

\section{Neem leaves:}

Neem leaves moisturize the skin and keep the hair delicate, supple and fixes skin break out. It is excellent agent for skin conditioning, skin lightening, evacuation of pimples, recuperation of sun burns. It is additionally utilized in dandruff expulsion and also resists microbial infection in hair and skin as well [2].

\section{Hibiscus:}

The hibiscus infused oil has shown tremendous result in boosting hair growth. Hibiscus has calcium, phosphorus, iron, vitamin $\mathrm{B}_{1}$, riboflavin, niacin and vitamin $\mathrm{C}$. These components are used to stimulate thicker hair growth and prevent premature greying of hair [7]. 


\section{Formulation and Examination of Organic Oil and Shampoo from Fish Scales}

\section{Curry leaves:}

Curry leaves has beta carotene in huge amount and proteins which can reduce hair loss and increase hair growth. They also contain amino acids and anti-oxidants which strengthen the hair follicles and moisturise the scalp. Curry leaves also helps to remove the dead hair follicles and can serve as ingredient against dandruff [9].

\section{Amla:}

Vitamin C, tannins and minerals such as phosphorus, iron and calcium in Amla provides nutrition to hair and also induces hair darkening. The surplus of vitamin $\mathrm{C}$ in amla can help to halt pre-mature greying [6].

\section{Coconut - oil:}

Coconut oil helps to prevent dandruff, promote hair growth, and helps to keep hair and scalp soft, healthy and silky. Coconut oil are known to possess anti- fungal and antibacterial effects. The vitamins and essential fatty acids found in coconut oil strengthens and nourish the scalp and help to remove sebum and built up from hair follicles [11].

\section{Aloe Vera:}

Aloe Vera pulp contains proteolytic enzymes which repairs the scalp dead skin. It works as a good conditioner and makes hair smooth and shiny [8].

\section{Soap nuts:}

Soap nuts, also known as reetha, soap berries have been used to make hair care products since years. This is rich in saponin that makes the hair shiny, healthy and lustrous when used regularly [10].

\section{Jasmine oil:}

It is well known for its sweet, light fragrance and aromatherapy. Jasmine oil is recognized to sooth the mind, relieve stress and reduce muscle tension. It serves as anti-microbial, conditioning agent and imparts good odor to the oil and the shampoo [8].

\section{Corn starch:}

Corn starch keeps our hair smooth and banishes the oiliness which is used for oily hairs. Cornstarch removes the excess oil and forms a soft film that makes hair dry and silky [12].

\section{TABLE 1: EVALUATION OF HAIR OIL AND SHAMPOO}

\begin{tabular}{|l|l|l|l|}
\hline S.No & Sources & Binomial name & Importance \\
\hline 1. & Fish scales & - & $\begin{array}{l}\text { Contain collagen which } \\
\text { induces keratin secretion }\end{array}$ \\
\hline 2. & Neem leaves & $\begin{array}{l}\text { Azadiarachta } \\
\text { indica }\end{array}$ & $\begin{array}{l}\text { Reduces of Dry scalp, } \\
\text { dandruff and hair fall } \\
\text { issues }\end{array}$ \\
\hline 3. & $\begin{array}{l}\text { Hibiscus } \\
\text { flower and } \\
\text { leaves }\end{array}$ & $\begin{array}{l}\text { Hibiscus } \\
\text { rosasensis }\end{array}$ & $\begin{array}{l}\text { Rejuvenate the scalp and } \\
\text { promote hair growth }\end{array}$ \\
\hline 4. & Aloe vera & $\begin{array}{l}\text { Aloe } \\
\text { barbadensis } \\
\text { miller }\end{array}$ & $\begin{array}{l}\text { Moisturizer and } \\
\text { conditioning }\end{array}$ \\
\hline 5. & Soap nuts & $\begin{array}{l}\text { Sapindus } \\
\text { mukorossi }\end{array}$ & Foaming agent \\
\hline 6. & Corn starch & Amylum & $\begin{array}{l}\text { Keeps hair moisture and } \\
\text { stimulates blood } \\
\text { circulation }\end{array}$ \\
\hline 7. & Jasmine oil & $\begin{array}{l}\text { Jasminum } \\
\text { oleaceae }\end{array}$ & $\begin{array}{l}\text { It is used for fragrance in } \\
\text { organic hair shampoo and } \\
\text { oil }\end{array}$ \\
\hline 8. & Amla & Phyllanthus & Anti-inflammatory, \\
\hline
\end{tabular}

\begin{tabular}{|l|l|l|l|}
\hline & (Seeds) & emblica & $\begin{array}{l}\text { Anti-bacterial, Rich in } \\
\text { Vitamin C, Anti-oxidants }\end{array}$ \\
\hline
\end{tabular}

\section{MATERIALS AND METHODOLOGY}

\section{A. Raw Materials collection}

The materials were collected from the natural sources. The ingredients are fish scales as a base, neem leaves, hibiscus flower and leaves, curry leaves, aloevera gel, soap nuts, corn Starch, jasmine oil, amla, sunflower seeds and coconut oil (Fig.1).

\section{B. Preparation of Organic Hair Oil:}

The materials were dried using hot air oven at $60^{\circ} \mathrm{C}$ and ground into small pieces using mixer grinder. Fish scales extract was prepared by boiling at $100^{\circ} \mathrm{C}$ and allowed to cool. The other dried materials (3:1) were allowed to mix with coconut oil and boiled for 15 minutes. The conical flask with these ingredients is kept at moderate shaking for 3 days. Finally, it was filtered through muslin cloth. To the filtrate, coconut oil was added to make up the volume to $100 \mathrm{ml}$. Small amount of jasmine oil was added for pleasant smell and the prepared oil was packed in a clean bottle (Fig.2).
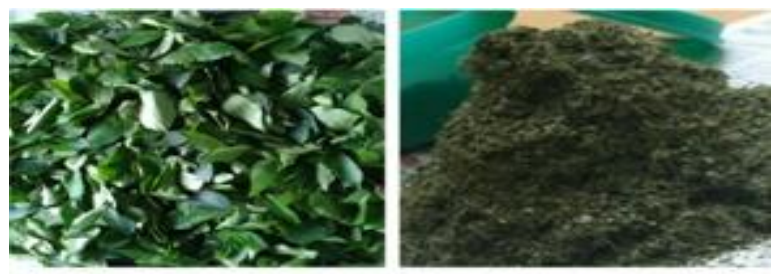

Murraya koenigï (Curry leaves)
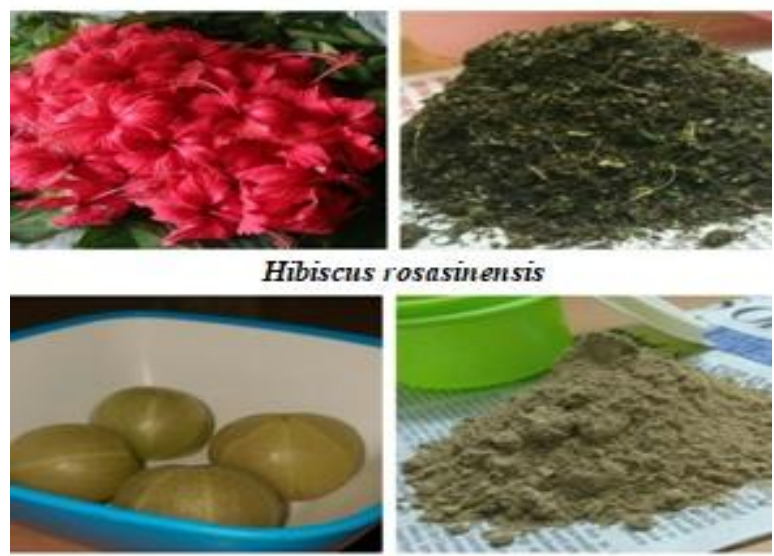

Phyllanthus emblica (Amla)

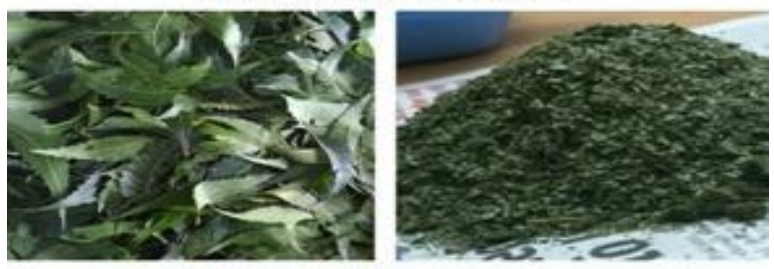

Azadirachta indica (Neem leaves)

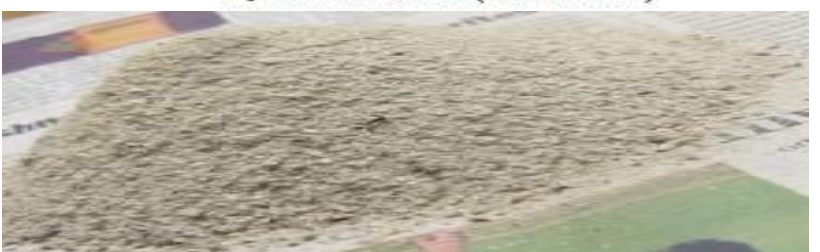

Fish Scales powder 


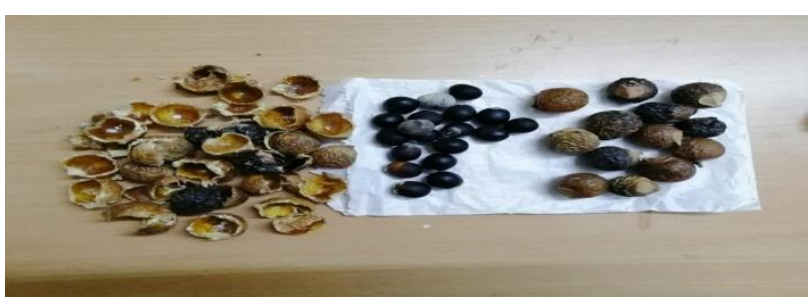

Sapindus mukorossi (Soap nuts) shampoo

\section{Preparation of Organic Hair Shampoo:}

The raw fish scales and other ingredients were dried in the hot air oven at $60^{\circ} \mathrm{C}$. Fish scales extract was prepared by boiling at $100^{\circ} \mathrm{C}$ and allowed to cool. The other dried materials were mixed with aloe-vera gel and boiled for 15-20 minutes at $75^{\circ} \mathrm{C}$. Finally, the extract was filtered through muslin cloth. The jasmine oil was added to the shampoo and was packed in a clean bottle (Fig. 3).

D. Evaluation of Formulated Organic Hair oil and Shampoo: The formulated organic hair oil and shampoo were evaluated for its physicochemical properties.

1. Homogeneity: The formulations were tested for the homogeneity by touch and visual appearance.

2. Appearance: The appearance of the hair oil and shampoo were judged and graded by its color, roughness.

3. Sensitivity test: The formulated organic hair oil and shampoo was spreaded onto $1 \mathrm{~cm}$ skin of hand and exposed to sunlight for 5 minutes.

4. Saponification value: $1 \mathrm{~mL}$ of the formulated oil was taken in a shakes flask and $10 \mathrm{~mL}$ of ethanol: ether mixture $(2: 1)$ was also added to it. To this, $25 \mathrm{~mL}$ of $0.5 \mathrm{~N}$ alcoholic $\mathrm{KOH}$ was added and was left undisturbed for 20 minutes. The flask was now cooled and the solution was titrated against $0.5 \mathrm{~N}$ $\mathrm{HCl}$ using phenolphthalein indicator. Similarly, the blank titration was performed without taking oil (sample).

Amount of $\mathrm{KOH}$ in mg used was calculated using formula,

Where,

$$
\text { Saponification Value }=56.1(\mathrm{~A}-\mathrm{B}) \mathrm{N} / \mathrm{W}
$$

$\mathrm{A}=$ Volume in $\mathrm{mL}$ of standard hydrochloric acid required for the blank.

$\mathrm{B}=$ Volume in $\mathrm{mL}$ of standard hydrochloric acid required for the sample.

$\mathrm{N}=$ Normality of standard hydrochloric acid.

$\mathrm{W}=$ Weight of the oil taken in grams for the test [13].

5. $p H$ : The $\mathrm{pH}$ of organic hair oil and shampoo were measured by $\mathrm{pH}$ meter [17].

6. Specific gravity: The specific gravity bottle was taken and washed with distilled water, dried for 15 minutes in oven, cooled, closed and weighed (a). Now, the same specific gravity bottle was filled with the sample and closed and again weighed (b). The weight was determined of sample per milliliter by subtracting the weight (b-a) [16].

7. Foam stability test: The stability of the foam was determined using cylinder shake method. About $50 \mathrm{ml}$ of formulated shampoo (1\%) solution was taken in a $250 \mathrm{ml}$ capacity graduated cylinder and shaken for 10 times
Fig. 1. Ingredients used for the preparation of organic hair oil and

vigorously. Foam stability was measured by recording the foam volume of shake test after 1 and 4 minutes, respectively [15].

8. Wetting time: The 1-inch diameter canvas discs were taken. Each disc was having an average weight of $0.45 \mathrm{~g}$. The disc was made to float on the surface of shampoo solution $1 \%$ $\mathrm{w} / \mathrm{v}$ and the stopwatch was started. The required time for the disc to sink was measured accurately and noted as $85 \mathrm{sec}$ wetting time [16].

\section{RESULT AND DISCUSSION}

\section{A. Preparation of Organic Hair Shampoo}

Thus an organic hair oil and hair shampoo were formulated by mixing the fish scales, Hibiscus rosasensis, Azadiarachta indica, Aloe barbadensis miller, Sapindus mukorossi, Jasminum oleaceae, Phyllanthus emblica and Amylum in a definite amount. The following are the figures of the formulated organic hair oil and organic hair shampoo.

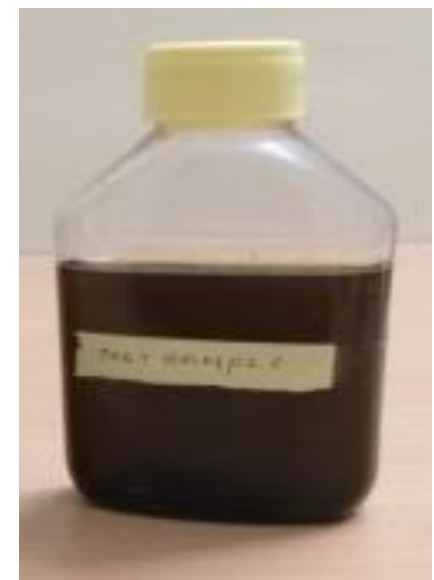

Fig.2. Organic hair oil

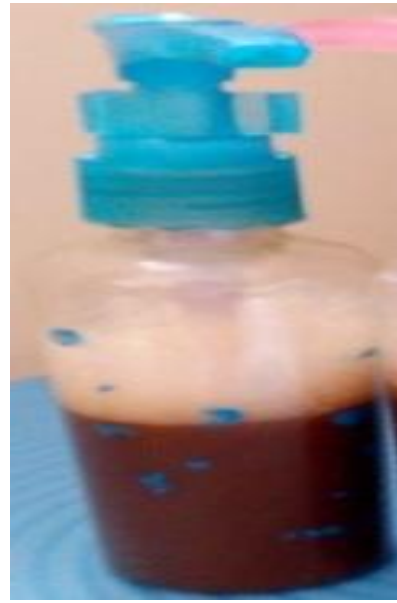

Fig.3. Organic hair shampoo

B. Evaluation of Formulated Organic Hair oil and Shampoo The results of physicochemical assessment of the formulation of organic oil and shampoo were recorded in Table 2 and Table 3. As can be seen, the formulations were very clear and had the great qualities as for frothing.

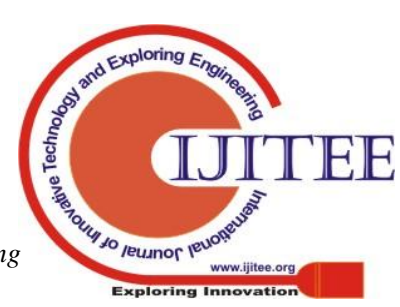




\section{Formulation and Examination of Organic Oil and Shampoo from Fish Scales}

The primary challenge with this detailing was of characteristic smell of Fish scales. That was adjusted with the addition of fragrance. The $\mathrm{pH}$ of the organic hair oil and shampoo were significant for upgrading and improving the evaluation of hair. The present pattern to promote organic hair oil and shampoo of lower $\mathrm{pH}$ is one of the approaches to limit damage to the hair. Mild acidity averts swelling and induce tightening of the scales, there by instigating shine. As seen from Table 2 and Table 3, the organic hair oil and shampoo were balanced and were ranged at $\mathrm{pH}$ near to the skin $\mathrm{pH}$. Likewise foam production and retention is significant as for consumer acknowledgment and palatability henceforth it winds up significant assessment parameter for the formulations. It has been mentioned that an appropriate cleanser should create froth which means that their great detergent action. The saponification value and the specific gravity of the shampoo makes formulation easy to apply on and easy to spread on hair. The hair oil and the shampoo did not show any skin irritation on application showing the safety of the constituent's present.

TABLE 2: PHYSICOCHEMICAL STUDY OF THE HAIR OIL

\begin{tabular}{|l|l|}
\hline Evaluation Test & Formulated Hair oil \\
\hline Sensitivity test & Non-sensitive \\
\hline Irritation test & Non-irritant \\
\hline $\mathrm{pH}$ & 6.5 \\
\hline Grittiness & Smooth \\
\hline Saponification value & 157.01 \\
\hline Color & Dark brown \\
\hline Odor & Aromatic \\
\hline Specific gravity & 0.95 \\
\hline
\end{tabular}

\section{TABLE 3: PHYSICOCHEMICAL STUDY OF THE HAIR SHAMPOO}

\begin{tabular}{|l|l|}
\hline Evaluation test & Formulated shampoo \\
\hline Color & Light Brown \\
\hline Transparency & Clear \\
\hline Odor & Aromatic \\
\hline $\mathrm{pH}$ & 6.2 \\
\hline Foam volume $(\mathrm{ml})$ & 25 \\
\hline Foam type & dense, small \\
\hline Wetting Time & \multicolumn{2}{|c|}{85} \\
\hline
\end{tabular}

\section{CONCLUSION}

Organic hair oil and shampoo are the most preferred cosmetic product has now created strong impact in our life. Organic oil and shampoo have several advantages over the synthetic shampoo and oil. Several organic ingredients offer anti-oxidant, anti-dandruff and its imparted glow for the hair. In this study, we formulated organic oil and shampoo using fish scales, neem extract, aloe vera, hibiscus extract, amla extract, curry leaves extract, corn starch, soap nuts, jasmine oil for fragrance and coconut oil for better stability and efficacy and evaluated its properties. Use of bioactive ingredients in the cosmetic formulations has tremendous effect on body features and provides nutrients. These are essential for maintaining a healthy and beautiful hair. It can be concluded that, the formulated organic hair oil has significant quality and can be employed for regular use for enhancing and maintaining hair growth.

\section{ACKNOWLEDGMENT}

We would like to acknowledge the management of Kalasalingam Academy of Research and Education (KARE) for the support and facilities provided for performing this work.

\section{REFERENCES}

1. https://en.wikipedia.org/wiki/Cosmetics

2. Simanchal Panda. "Formulation and evaluation of herbal powdered shampoo". Journal of Emerging Technologies and Innovative Research. vol 5. pp. 108-113.

3. Anand S. Kahalekar \& Bhaishajya Kalpana. "A review from booty to beauty: an attempt to unearth ayurvedic cosmeceuticals". Int. J. Res. Ayurveda Pharm. vol 9 (3). 2018. pp. 14-16

4. Aurora Alessandrini and Bianca Maria. "Essential of Hair Care Cosmetics", Cosmetics. vol 3. 2016. pp.1-10.

5. https://draxe.com/fish-collagen/

6. Wagner H, Bladt S, Zgainski FM. Plant drug analysis Verlas, Berlin. 1994; 291-304.

7. Adhirajan N., T. Ravi Kumar, Shanmugasundaram N. and Mary Babu, J. Ethnopharmacology,2003; 88, 235-239.

8. Rahathunnisa begum and Afzalunnisa begum. "Preparation and evaluation of herbal hair oil". International Journal of Research and Analytical Reviews. vol 6, 2019.

9. X. Fatima Grace, S. Rahul Raj, S. Shanmughanathan, D. Chamundeeshwari. "Preparation and evaluation of polyherbal hair oil". International Journal of Pharmaceutical Chemistry and Analysis, vol 1. 2014. pp. 1-5

10. Seema Yuvraj Mendhekar, Arti Shantaram Tajane, Pratiksha Balasaheb Shitole, Jadhav S. L. and Gaikwad D. D. "Formulation and evaluation of polyherbal shampoo and compare with marketed shampoos", World Journal of Pharmacy and Pharmaceutical Sciences. vol 6. pp. 1388-1397,

11. https://www.thestreet.com/lifestyle/health/benefits-of-coconut -oil-14776575

12. https://theindianspot.com/use-cornstarch-oily-hair/

13. Rahathunnisa begum and Afzalunnisa begum. "Preparation and evaluation of herbal hair oil". International Journal of Research and Analytical Reviews. vol 6. 2019. pp. 266-269

14. Vijayalakshmi.A, Sangeetha S, Ranjith N. "Formulation and evaluation of herbal shampoo". Asian J Pharm Clin Res, vol 11, 2018, pp. 121-124.

15. Indian Pharmacopoeia, Government of India, Ministry of Health and Family Welfare, Published by, The Controller of Publication, Edition, Vol. II (1996).

16. Klein K. "Evaluation of shampoo foam". Cosmet Toilet Mag. 2004. pp. 32-5.

17. Badi KA, Khan SA. "Formulation, evaluation and comparison of the herbal shampoo with the commercial shampoo". J Basic Appl Sci. vol 3. 2014. pp. 301-5 


\section{AUTHORS PROFILE}

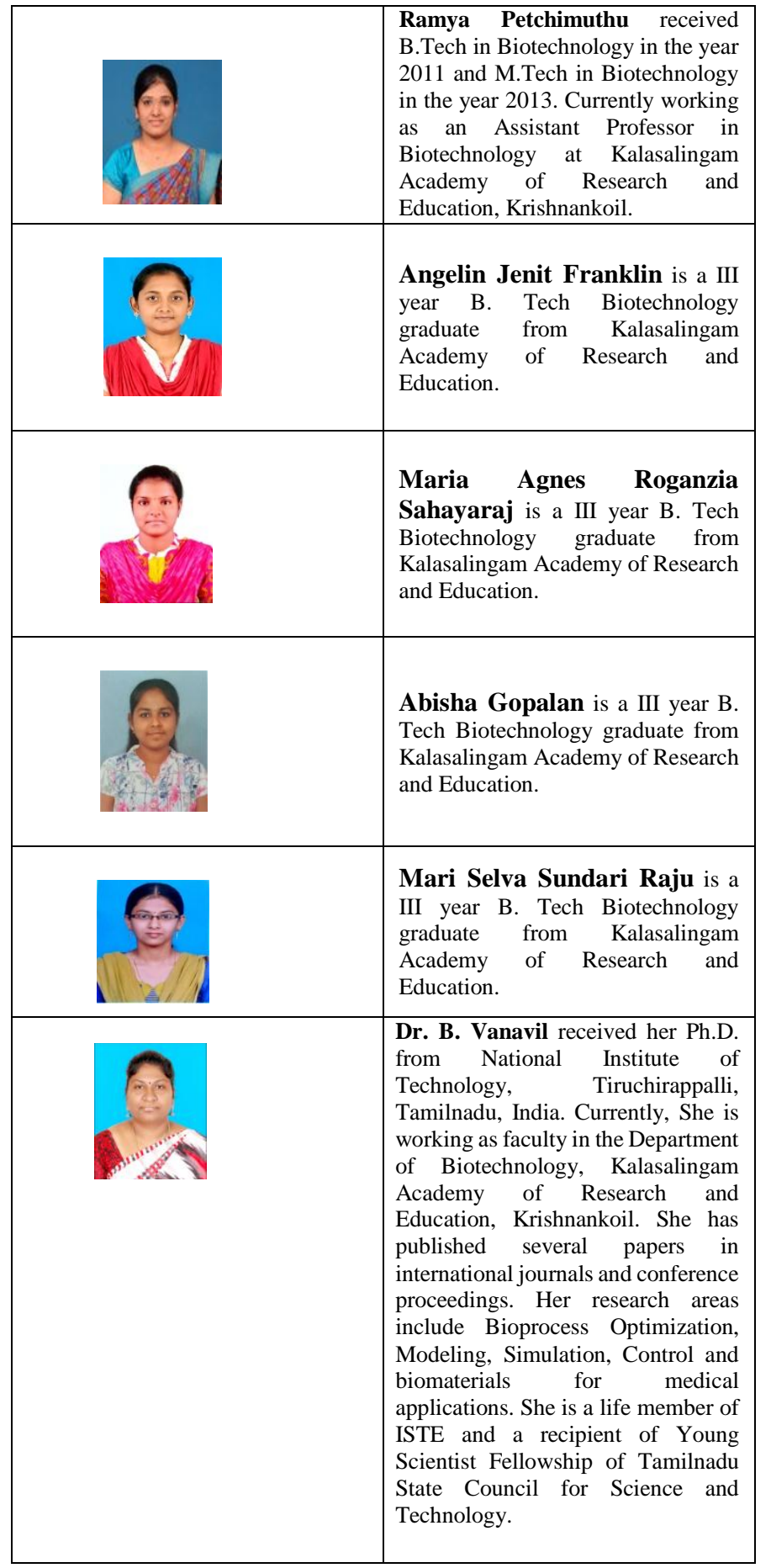

